Özet

MSÜ'nin geçirdiği son mekânsal değişiklikler, Kurum'un inşai ve sosyal tarihine ait anıların, düşüncelerin tekrar gündeme gelmesine sebep olmuştur. Bugün MSÜ'nin merkez binaları olarak kullanılan Cemile ve Zekiye Sultan Sarayları'ndan (1860)

Kabataş İskelesi yönündeki Cemile Sultan Sarayı 1926'da Akademi'ye verilmiş ve 1948'deki yangına kadar orijinal haliyle kullanılmıştır. Zekiye Sultan Sarayı ise, 1970 yılında Akademi'ye verilmiştir. Cemile Sultan Sarayı, 1948'deki yangından sonra Sn. Sedad Hakkı Eldem ve

Sn. Mehmet Ali Handan Hocalar tarafından hazırlanan proje doğrultusunda yeniden inşa edilmiştir. Zekiye Sultan Sarayı da 1970'lerde yine aynı ekip tarafından restore edilmiştir. Bu renovasyonlardan sonra her iki bina da eski hallerine göre daha renksiz ve çıplak olmalarına rağmen yapı boyunca derinliği algılamaya olanak veren boşluklar, ferah, aydınlık, nefes ve 1 şık alan iç mekânlar oluşturuyorlardı. Her iki bina da mimarî özelliklerini, yapıdaki mekân yetersizliği sebebiyle, bina içindeki

boşlukların, avluların kapatılarak, yapının karakterinde zedeleyici düzenlemeler yapılana kadar korudular. Üniversitemiz'e yeni binalar verilmesi ve her yıl

Üniversite'ye katılan öğrenci sayısının makul bir ölçüde tutulması, varolan mekân yetersizliği probleminin çözümünde bir ilerleme sağlayacaktır.

Summary

The latest spatial renovations in Mimar Sinan University bring forth some thoughts and reminiscences about the social and architectural history of the institution. The Cemile and Zekiye Sultan Palaces today

constituting the main buildings of the University were built in 1860. The former building which was used in its original form until the fire in 1948 was given to the Academy of Fine Arts in 1926. Professors Sedad Hakkl Eldem and Mehmet Ali Handan prepared new renovation projects modernizing the original architectural concept for the Cemile Sultan

Palace after the fire and for the Zekiye Sultan Palace after it was given to the Academy in 1970. Although they were plain and colorless compared to their original states, the buildings now had spacious, luminous interiors, which allowed light and air to flow in. The buildings preserved their original spatial configurations until the voids and courtyards were built over in order to provide space for new studios and offices.

The current problem of space that the University needs may be resolved by the allocation of new buildings and by limiting the

number of students accepted each year. Anahtar Kelimeler

Devlet Güzel Sanatlar Akademisi, Mimar Sinan Üniversitesi, Eğitim Yapıları. Keywords:

Istanbul State Academy of Fine Arts, Mimar Sinan University, Educational Buildings.

\section{Tasarım ve kenarda kalan}

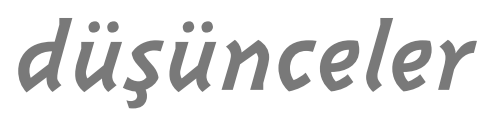

Prof. Muhlis Türkmen MSÜ Mimarlık Fakültesi,

Mekân Organizasyonu ve Donatımı Bilim Dalı

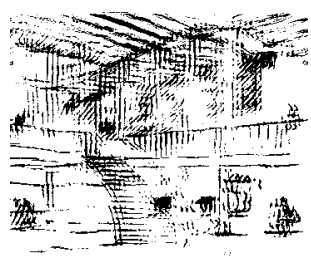

Mimarlık mesleğinde tasarım ve uygulamaları izleyen dönemlerde mekanlarda baş gösteren gereksinimler, yapılarda kaçınılmaz değişikliklere neden olmuş ve olmakta devam etmektedir. Haklı olarak ve açıkça kendini belli eden bu gibi istekler sonuçta planlarda yüklenme ve zorlamalar yaratmaktadır.

Üniversitemizin merkez yapıları olarak tanınan Fındıklı'daki ana yerleşim mekanlarımız da bu yüklenmenin sıkıntısını çekmektedir. Üniversitemiz yetkililerinin uzun bir zaman dilimi içinde yapmış oldukları başvurular doyurucu bir biçimde yanıtlanmamıştır. Gereksinme ve sıkışıklık her zamanki gibi devam etmektedir.

$\mathrm{Bu}$ yersizlik ve yetersizliklerin bir an evvel sonuçlanması başvuruların karşılanması ile mümkün olacaktır. Zaten yazının başlığında geçen "Kenarda kalan düşünceler" anlatımı da kısmen bu olmaktadır.

Bahse konu bu yapılar içinde öğrencilik günlerim hariç yarım yüzyılı geçen bir yaşantının sahibiyim. Bugün Mimar Sinan Üniversitesi'nin merkez binaları olarak kullanılan Cemile Sultan ve Zekiye Sultan adı ile anılan Çifte Saraylar gerek

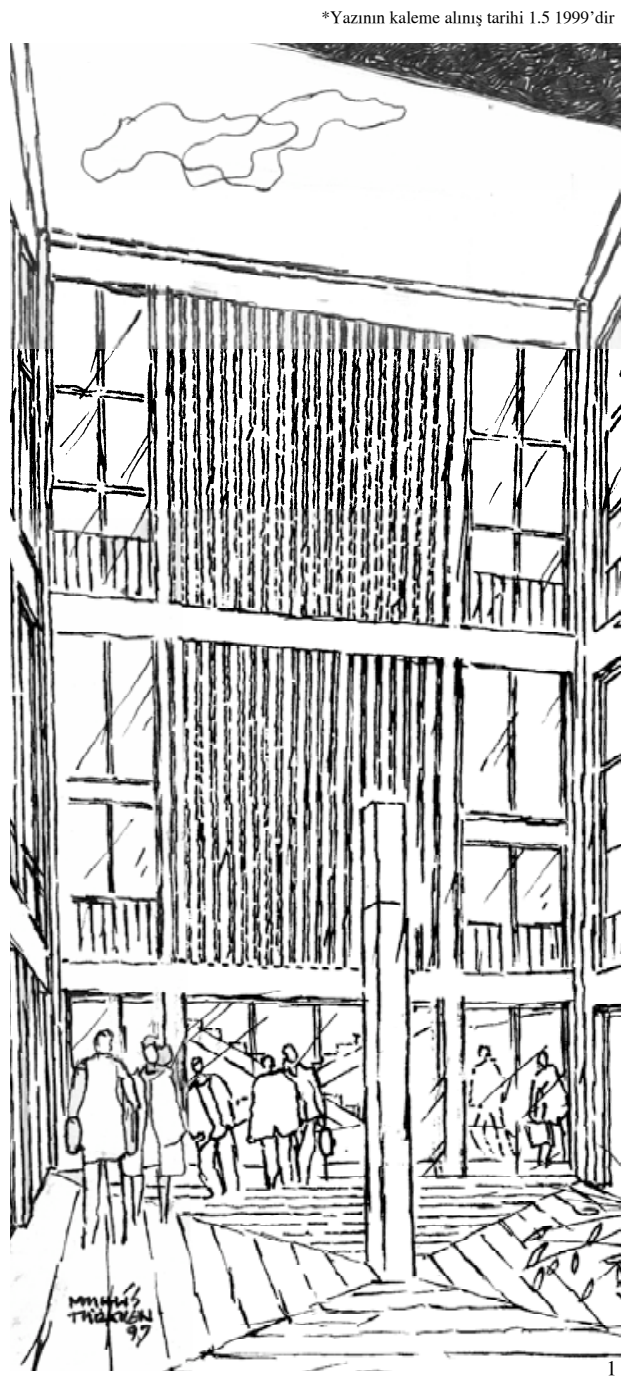

Sayı I, Mayıs 1999 I 
Tarihleri (1860) ve gerekse mimari değerleri ile birinci derece mimari mirasımız olan yapılardır. Bununla ilgili olarak ufak bir tarihsel gezi yaparsak konu hakkında olayları geniş bir açıdan görmüş olacağız. Üniversitemizin Kabataş İskelesi yönündeki merkez binalarından ilki olan ve Akademi'ye 1926 yılında Atatürk'ün emirleri ile verilen ve daha evvelce de "Meclisi Mebusan Binası" olarak kullanılmış olan Cemile Sultan Saraylarıdır. Bu yapı 1948'de bir elektrik kontağı sonucu yanmıştır. Tophane yönündeki diğer bina ise Zekiye Sultan Sarayı olup 1970 yılında Akademiye verilmiş ve ancak onarılmayıp yeni bir proje uygulaması sonucunda eğitime açılmıştır (Resim 1, Resim 1 a).

Devlet Güzel Sanatlar Akademisi (Cemile Sultan Saray1), 1 Nisan 1948'de yandıktan sonra ( Resim 2 a) yerine bugünkü Üniversi-te'nin Rektörlük, Genel Sekreterlik ve Güzel Sanatlar Akademisinin büyük bir bölümünü içine alan merkez binası yeniden yapıldı. Yangından bugüne sadece ve sadece eskiyi hatırlatan cepheler kalmış, ana taşıyıcı duvarlardan bir kısmı hariç, giriş saçağı, kesintiler, aydınlıklar, merdivenler tamamen değiştirilmek suretiyle ve ana düşünce kaybolmamak üzere yeni bir planlamaya göre inşa edilmiştir (Resim 3-4).

Akademi idaresince proje işleri, atölye hocaları Kuruluna verilmişti. Yapılan toplantıda Kurul üyelerinden birer öneri proje istendi; sonuçta Sayın Sedad Hakkı Eldem ve Mehmet Ali Handan hocaların ortaklaşa hazırlamış oldukları proje ekseriyetle kabul edildi. Adı geçen projede tüm diş duvarlar korunmak suretiyle yapının içi betonarme kolanlarla hafifletilerek geniş avlulara yerverilmiş olup, ferah ve aydınlık mekanlar elde edilmişti. Bugün gibi hatırlıyorum, tasarım Yanan yapının rölövesinin bir ozalit kopyası üzerine elle ve bir dolma kalemle çizilmiş olup tümüyle güzel bir biçimde proje anlatılıyordu. Tekrar ediyorum Sedad Hakkı Eldem hocanın bu eskiz niteliğindeki çizgilerini o günlerden bugüne önemle

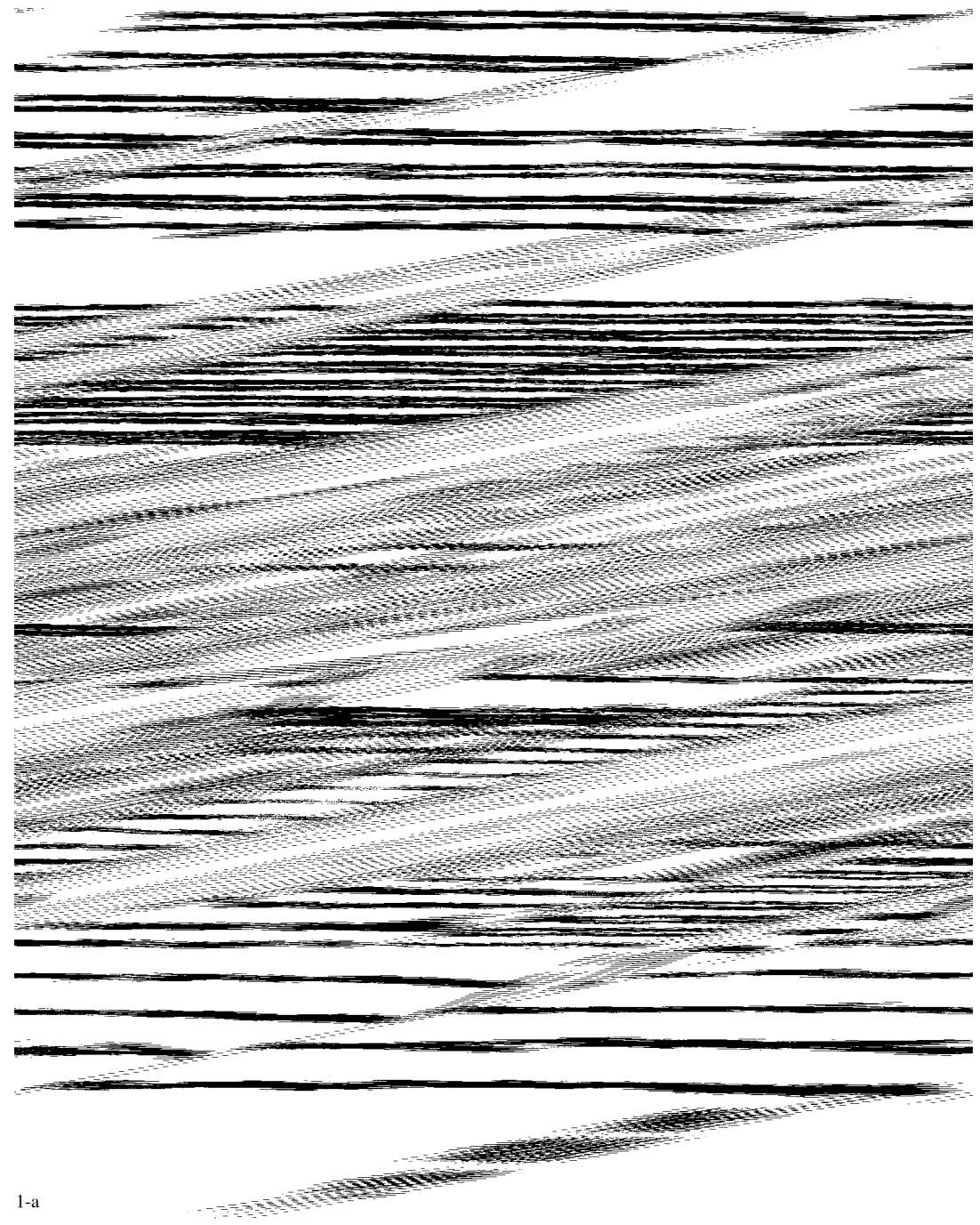

hatırlarım. Bu çizgiler berrak, temiz ve ne olduğunu, neler yapmak istediğini bilen bir çizgi türü idi. Ölçülü ve inşai bir karakteri vardı. Tek kelime ile Sayın Sedad Hakkı Eldem hocamızın kişiliğinin ve mimarisinin işareti sayılabilirdi. Hayran kaldığım bu çizimleri sonradan hiçbir neşriyatta göremedim, keşke bu krokiler korunarak Mimar Sinan Holünün uygun bir yerinde devamlı sergilenebilseydi derim. O tarihlerde muhterem hocam Prof. Arif Hikmet Holtay'in Bina Bilgisi kürsüsü ve proje Atölyesinde asistan olarak görevliydim. Kendilerine çok şeyler borçlu olduğum hocamı her zaman rahmetle anarım. Kendilerinin düşüncelerini aksettiren ve eskinin tamamına yakın tekrarı olan proje

Resim: I Her iki yapıyı doğal aydınlatma ve havaya kavuşturan aydınlıklar (avlu) Resim: 1-a Mimar Sinan Holü'nden avluya bakışta doğal aydınlatma ve mekân derinliği 
verilmek üzere çizmiş idim (Resim 5) . Bu tarihsel bilgiyi de bir anım olarak belirtmeyi uygun buldum. Bu asistanlık görevim sebebiyle, gene asistan olan sayın Veysi Selimoğlu ve Muhteşem Giray ile beraber idarece uygulama projelerinin çizimleri için görevlendirildik.

$\mathrm{Bu}$ projeleri Akademinin yanmasından sonra yerleştirildiğimiz ve bugün Yıldız Üniversitesinin kullandığı eski Mülkiye Mektebi binasında büyük bir zevkle çizdik.
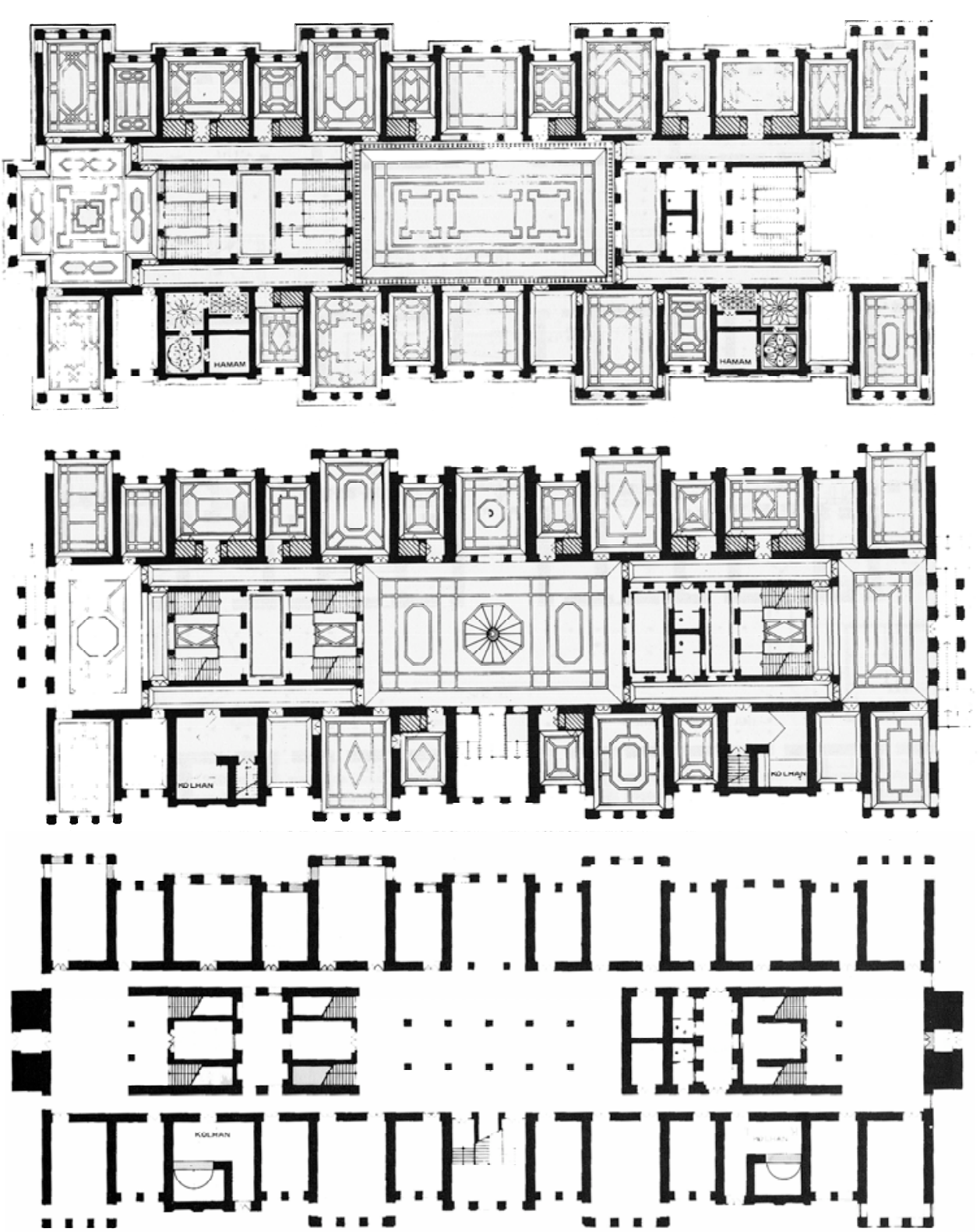

Sayı I, Mayıs 19993
Mehmet Ali Handan hocalarımızın projeyi takiplerini ve bu işe gösterdikleri ilgiyi hatırladıkça mesleğimizin önemini anlıyorum. Bu nedenle meslek hayatımda bu konudaki atölye çalışmalarını unutamam. Daha sonra uygulamaya geçildi ve yap1 23 Nisan 1954 tarihinde tamamlanarak eğitime açıldı.

Akademi, yangından evvelki haliyle, iç mimarisiyle saray halini daha doğrusu bir Güzel Sanatlar Akademisi görüntüsünü
(I.kat Planı) Cemile ve Zekiye Sultan sarayları kat röleve planları "Akademi Binasi'na çeurilmeden evvel çifte Saraylar olarak 1860'larda yapilmis olan Boğaziçi'nin ilk kagir yalılarından olan binanın üç katına ait rölöve. Orta kısmının ve ahşap dösemelerinin yıkılmaları zorunlu idi. Ilk tamir yapilan bina, daha evvelden yanmıs (1948) ve harabe halinde idi." 
sergiliyordu. Avizeleri, özel olarak Hereke'de dokunmuş yekpare halıları, Goya, Velasquez, Ingress' in orijinal tablolarının kopyaları ve vitraylı pencereleri ile özgün bir bina idi ve en önemlisi hoca ve öğrencilerinin tümünün beyaz önlükleri bulunuyordu.

Yeni binanın mekanlarında ise bariz bir çıplaklık ve renksizlik hakimdi. Göze batan bir hal de beyaz çalışma önlüklerinin yokluğu idi. Bu görünüşü bugün bile silemedik. Buna karşılık üstün olan tarafı ferahlığı, aydınlığı ve bir bakışta yapı boyunca derinliği algılayabilmekti (Resim 6). Bizler binanın bu havasını avluları ile yüksek tavanlı mekanları ile yıllarca soluduk.

Kısaca verilen bu tarihi bilgi ışı̆̆ında yapılan ilavelerin nedeni ne idi? Yanıt yukarıdaki satırlarda da işaret ettiğim gibi mekanlardaki kullanım yetersizliğidir.

Tekrar geçmişe döndüğümüzde ele alınan ikinci yapı da (Zekiye Sultan Sarayı) aynı plana sahipti. Bir müddet sırasıyla İstanbul Üniversitesi Edebiyat Fakültesi, Birinci Ordu Komutanlığ 1 ve Atatürk Kız Lisesi olarak kullanıldıktan sonra 1970 yılında Güzel Sanatlar Akademisi'ne devredildi. Ahşap tavanları ve merdivenleri ile göz dolduran bu yapı aşırı derecede harabiyeti dolayısı ile tamire muhtaçtı. İkizinin bir yangin sonunda tamamen yok olması yanında böylesine bir tehlike tekrar göze alınamazdı.

Prensip olarak dış duvarları ile taşıyıcı iç ana duvarları bırakılmak suretiyle tamamen yıkılarak bugünkü haline dönüştürüldü. 1. Merkez binada uygulanmış olan düşünce Sayın Sedad Hakkı Eldem ve Mehmet Ali Handan hocalar tarafından bu yapıda da aynen uyguland. Ekte sunulan eski ve yeni planların tetkikinden açıkça görülüyor ki, birinin yanması ve diğerinin ise aşırı derecede onarıma gerek duyulması gibi zorunluluk dolayısıyla planların ilk tasarım esaslarına dayanılarak korunması hususunda bir

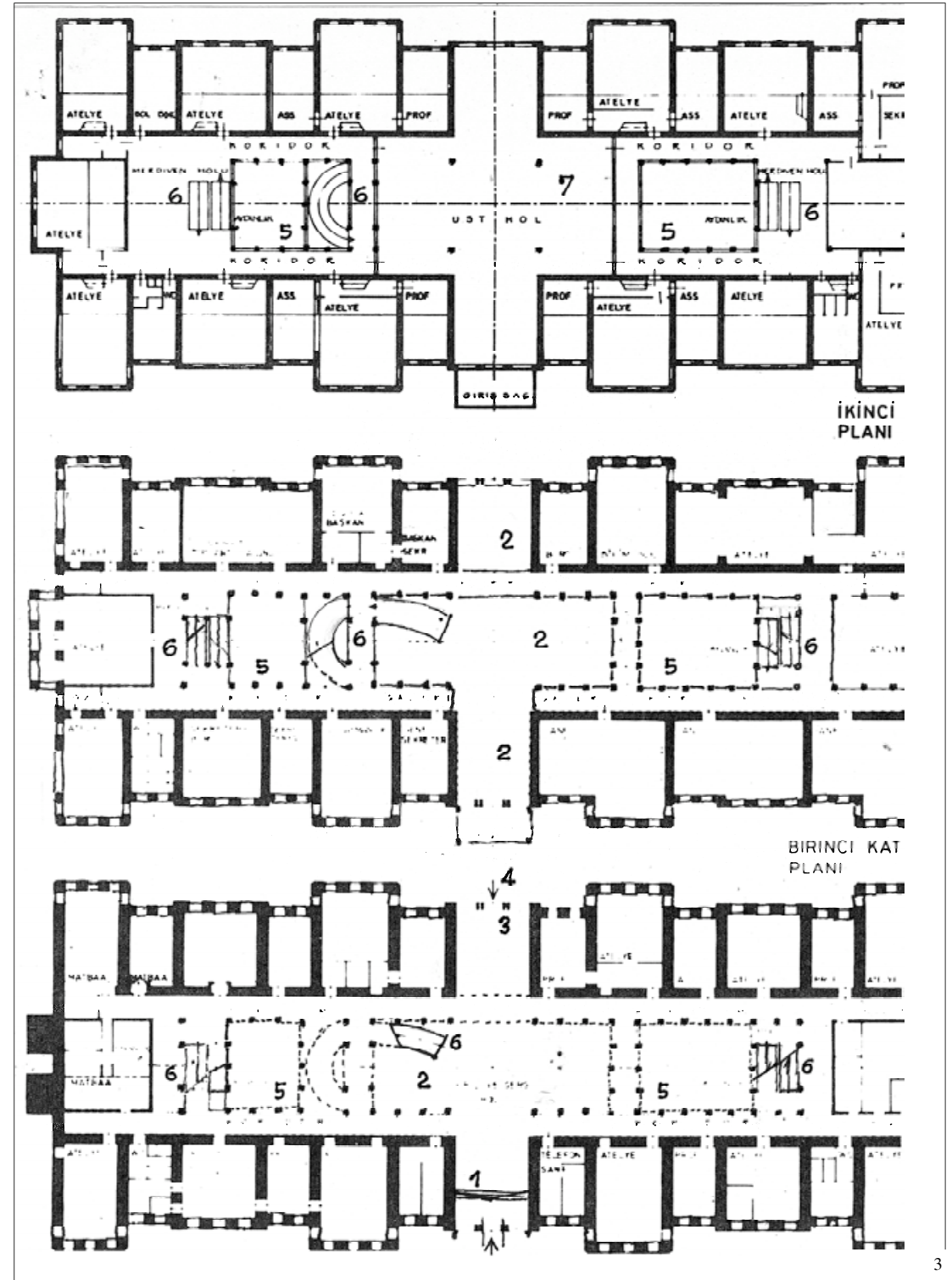

gayretin sarfedilmiş olduğu görülür; Şöyle ki, her iki yapının betonarmeye dönüştürülmesinde eskinin karakteristiklerini korumak gaye edinilmiş ve bu düşüncelerle sonuçta elde edilen yapılar bizlere kalan birer mimari miras niteliğini kaybetmemişlerdir. Planlar incelendiğinde ileri derecede bir değişime uğratılmadan binalar tekrar yeni ve yaşanır bir hale getirilmiştir. Bahse konu bu mimari düşünce ve uygulama saray kalıntısından tamamen siyrılıp, genç dinamik ve onurlu bir mimariye gidişin bir anlatımı olarak da kabul edilebilir.
Resim: 3 Giriş Kat Planı Akademi birinci kısım yenilenmesine ait planlar (1945-50). Yikılan orta kisım tamamiyla boşaltılarak betonarmeden yeniden inşa edilmiş, bu arada zemin katı biraz yükseltilerek daha kullanışlı bir hale sokulmuştur. Aydınlıklar ve cam duvarlar sayesinde binanın içi tamamıla şeffaf ve aydınlık olmuştur. 


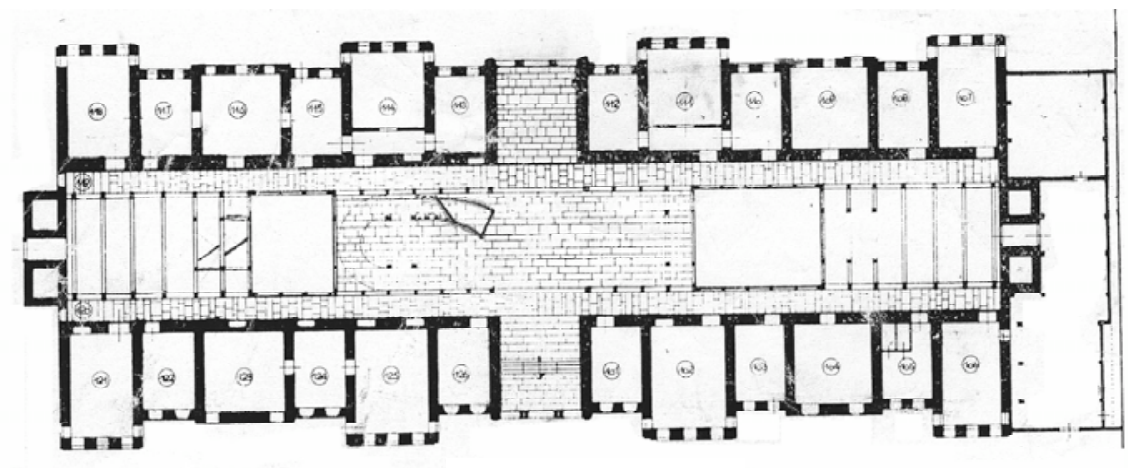

Zemin Kat Planı

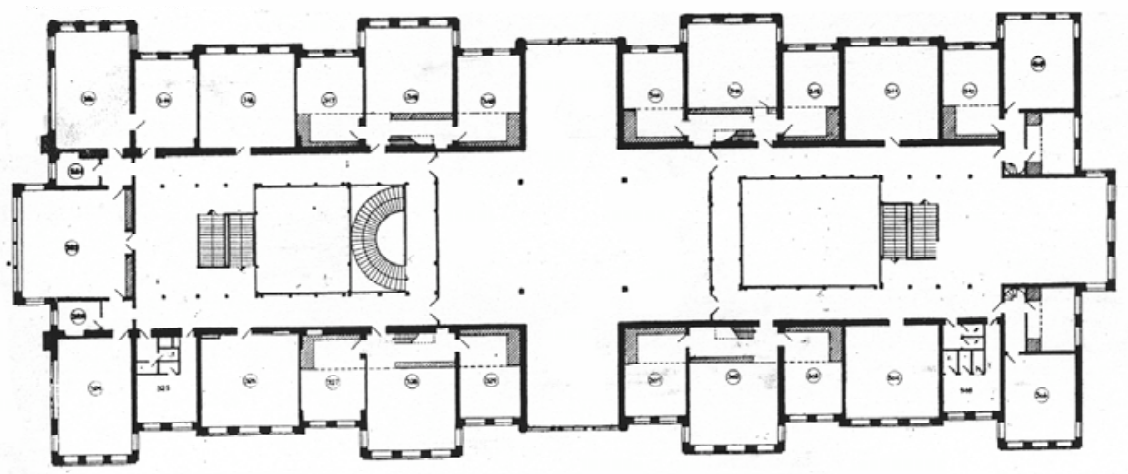

İkinci Kat Planı

Resim: 4

Cemile Sultan Sarayı

Akademi'nin Restorasyon Projesi

(Prof. Sedad Hakkl Erdem,

Prof. Mehmet Ali Handan)

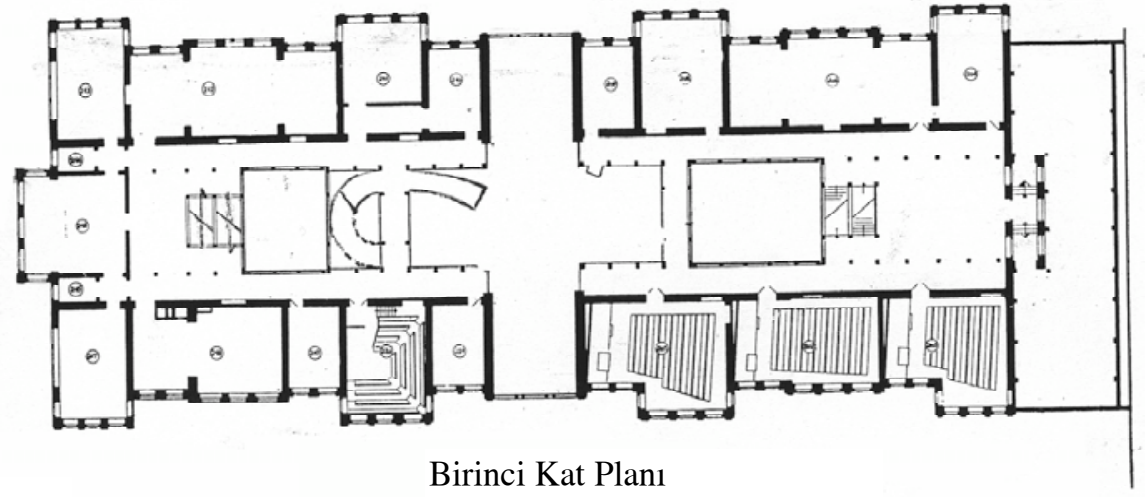

Sonuç itibariyle, bu tasarımlarıyla her iki yap1 da bizlere kalan birer mimari miras idiler ve öyle sayılmaları da bence normaldir. Her iki yapıda yapılan en büyük ve en güzel değişim kesitlerde olmuş, rutubet ve diğer bazı nedenlerle kısmen kullanılan bodrum kat zemin katla birleştirilerek faydalı bir duruma getirilmiş ve bu değişiklikle iç mekanlar ve bilhassa sağ ve solundaki avlularla
Mimar Sinan ve Osman Hamdi Bey girişi holleri olağanüstü bir aydınlığa ve ferahlığa kavuşmuştur(Resim 7-8-9).

$\mathrm{Bu}$ hava her iki binanın ikinci derecedeki merdiven hollerinde ve koridorlarında da devam ettirilmiştir. İnce, zarif, betonarme kolonlar ve luxferlerden sızan günışı $\breve{g}_{1}$ nervürlü tavanları da aydınlatıyor. Deniz ile bahçe arasında içiçe boydan boya 
uzanan mekanlar birbirlerini takip ediyordu. Mekanlarda eskinin zihinlerde kalan loşluğu ve basıklığı artık hissedilmiyordu. Eksik olan, özel suretle Hereke'de dokunmuş yekpare halı, avizeler ve holleri süsleyen Goya, Velasquez ve Ingress gibi ustaların kopyaları ve holün ortasındaki muhteşem avizenin altında yer alan mermer masa ve vazo içinde günlük çiçeklerdi.

Yazımın başında bu yana sık sık geçen kelime olan "yersizlik" bu ikinci yapıda da kendini göstermiştir. Bu zorlama ister istemez planlarda değişmelere, ilavelere neden oldu. Bu çalışmalar bazen esas bazen de ikinci derecede yer alan perspektivlerin (Resim 10) hafiften değişmesi sonucunu yarattı.

Gösterişsiz (mütevazi) bir iç görünüş veren ve mimarı bir miras olarak kalmalarını dilediğim her iki yapının evvelce de işaret ettiğim gibi fazlaca yüklendiği ve zorlandığı hakikatını tekrarlamakta fayda görüyorum.

Bu konuda her toplantıda, açılışlarda yıllar boyu devam edegelen masum, haklı bir isteğimizdi. Başta Reisicumhur Sayın Süleyman Demirel olmak üzere bakanlar ve milletvekilleri birçok vaatlerde bulundular. Çok ümitlendik ama sonunda tüm bu uğraşlarımızın boşuna olduğunu anladık. Üniversite binalarının yanıbaşında bulunan ve bir ucu Nusretiye Camii'ne dayanan mevcut antrepoların yapısal durumları yeni kullanımları mümkün
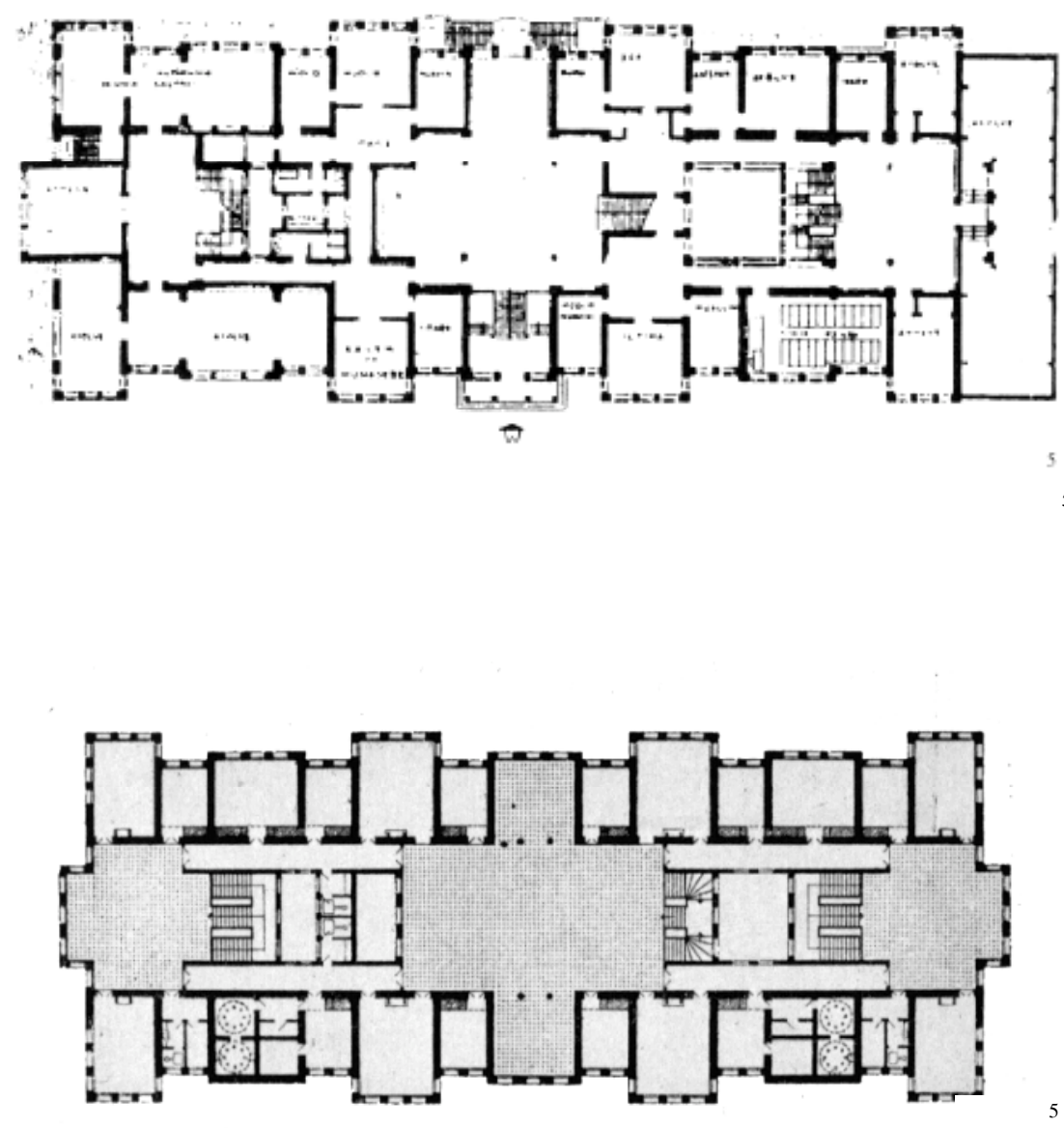

Resim: 5

kılabilecek nitelikte de olduklarından bu yapılar korunmak süretiyle zemin katlarında arkadların oluşabileceğ $\mathbf{i}$ biçimde planlanıp ticaret, sergi, kahve ve lokantalar üst katların ise Mimar Sinan Üniversitesi'nin atölye, kütüphane, müze, sergi bilimsel çalışmalarına açılması
Akademi idaresince uygulanmasi önerilen proje (Prof. Arif Hikmet

Holtay)

Resim: 5 a

Akademi Röleve projesi

Resim: 6

Bu planda her iki binada da varolan mekânların bağlantılarının devam edişi görülmektedir.

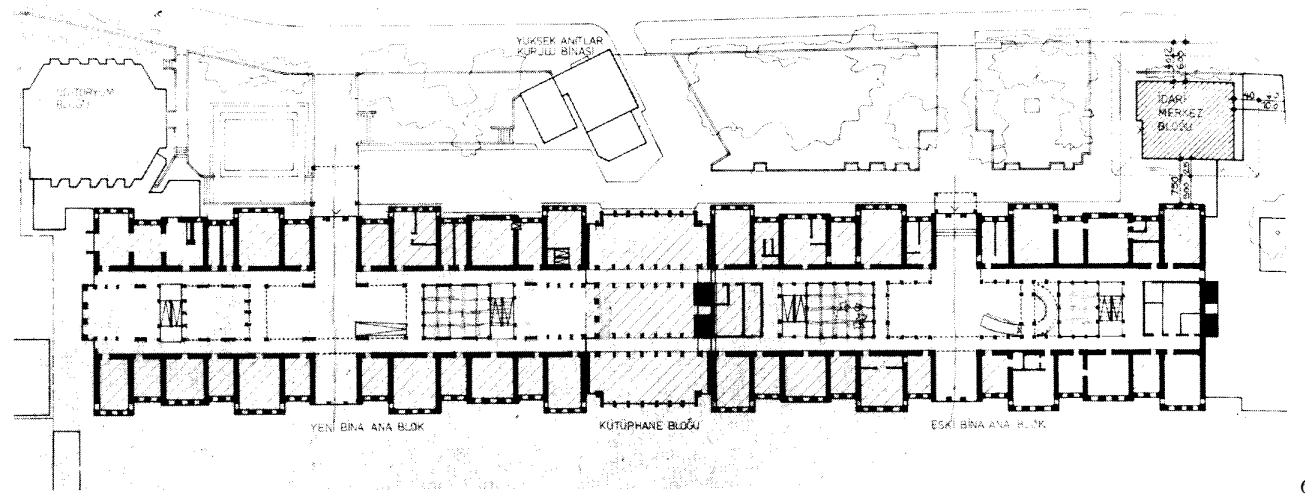

6 Sayı I, Mayıs 1999 


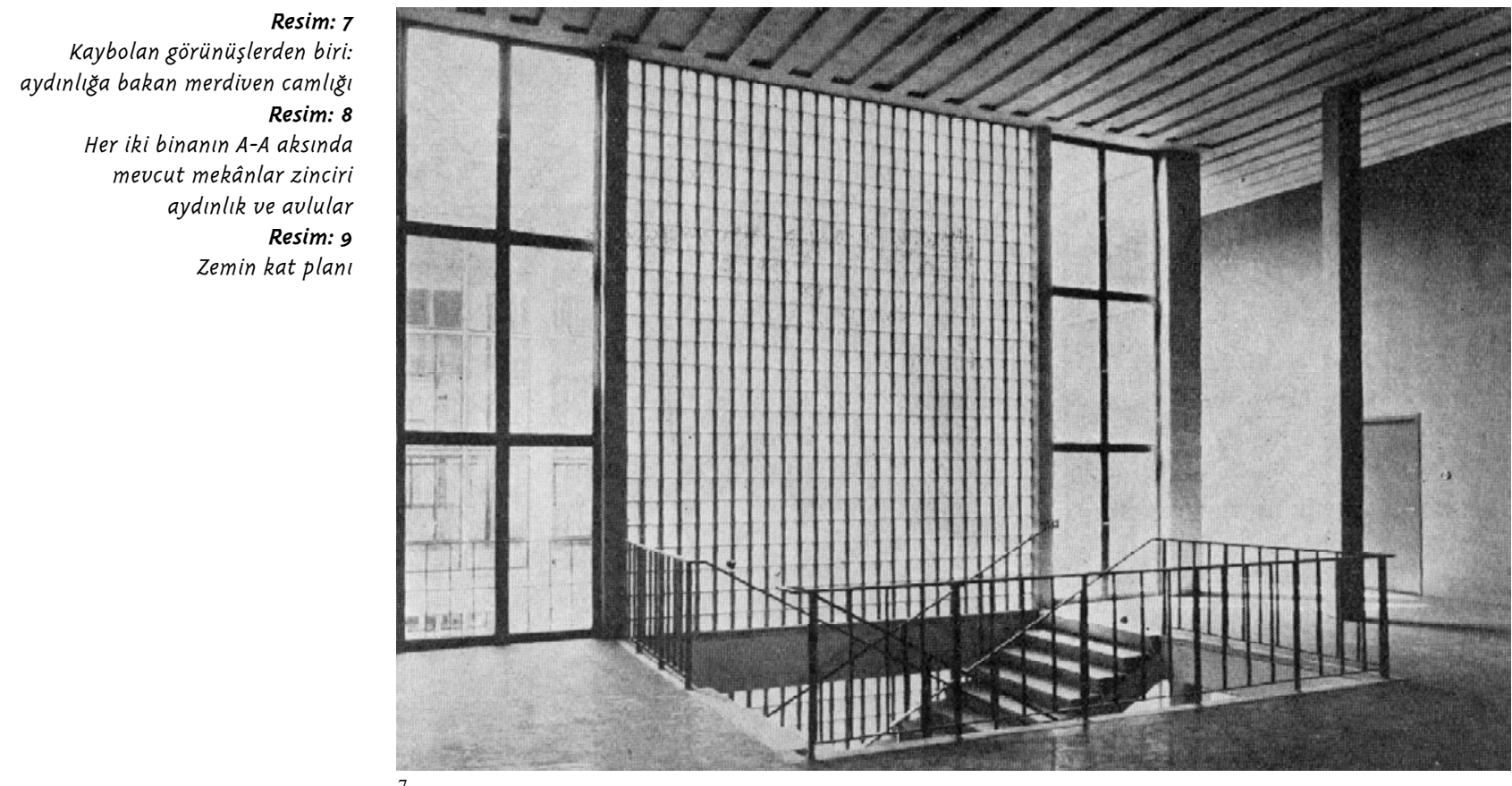

düşüncemizi istek üzerine "Tophane, Salıpazarı Kültür Eğitim Ticaret Turizm Merkezi Mimari Fikir Projesi” olarak Üniversite Rektörlüğüne sunduk. (Mimarlar: Tuncer Çakmaklı, Rıdvan Kutlutan ile birlikte). Tahmin ediyorum bu anlamda birkaç proje daha verilmişti. $\mathrm{Bu}$ konuda temaslar hangi noktadadir bilmiyorum. Basından Salıpazarı bölgesinin bir turizm Merkezi olarak projelendirilmesinin düşünüldüğü haberini aldık. Üniversitemizin bu bölgede olması icap eden haklarının hangi ölçüde kabulü hakkında henüz bir bilgimiz yok. Haklı taraflarımızdan biri de 1950'lerde Meclisi Mebusan Caddesinin genişletilmesiyle Devlet Güzel Sanatlar Akademisi'nin bugünkü adıyla Mimar Sinan Üniversitesinin kaybetmiş olduğu arsa ve yapıların bir hayli fazla oluşudur(Resim 11).

Net bir biçimde yersizlik sıkıntısı çekilmektedir. Bu durumu hiç bilmeyen ilgili

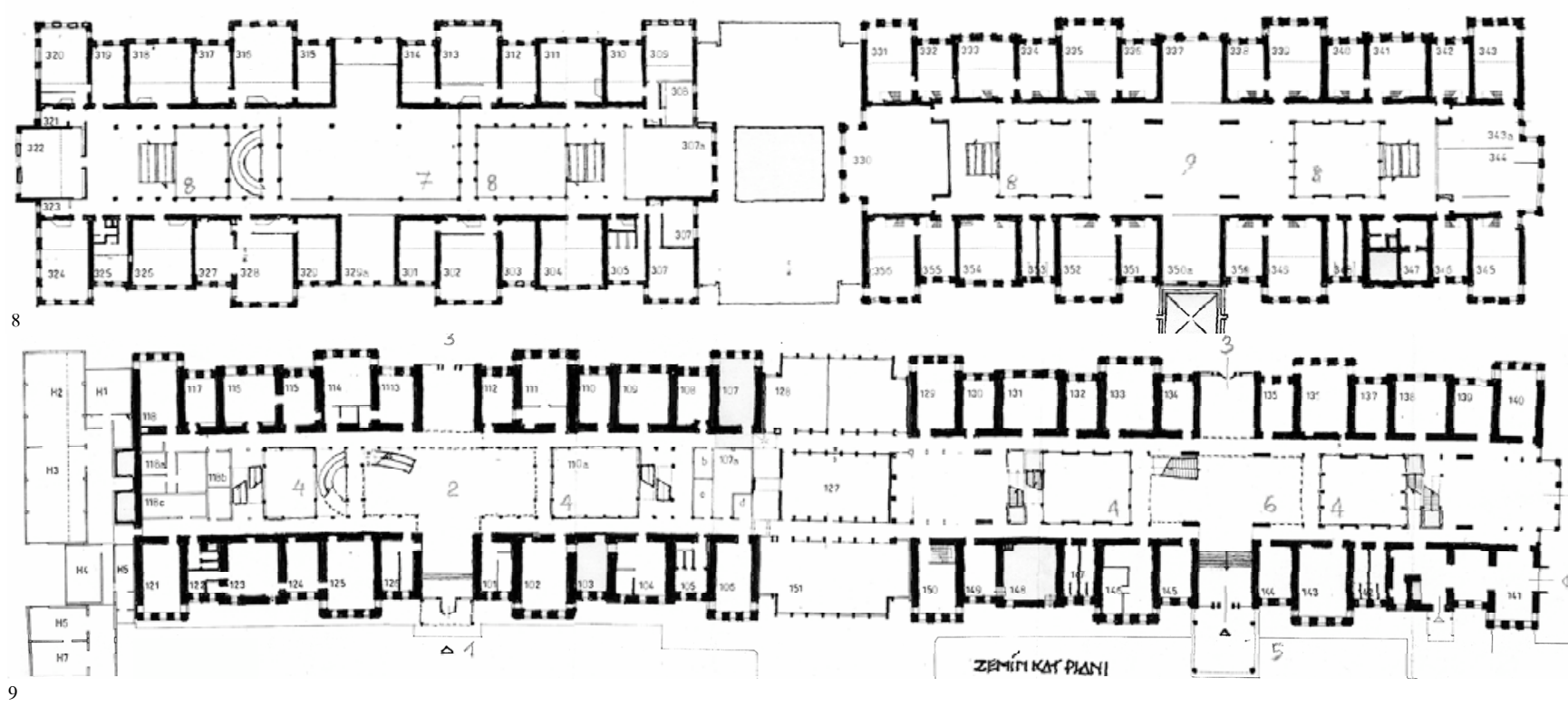


ve yetkili bir kişinin binalarımızı baştanaşağı bir defa gezmesi o kişiye çok şey anlatabilir. Dileğimizi yer sıkıntımızın bir an önce giderilmesidir. Aksi halde Üniversitede eğitim hol ve koridorlara sirayet edecek ve belki de kifayetsiz olan bahçede çadır kuracağız. Eğer bu tablo seyredilmek istenmiyorsa ricamız yeni binalar tahsisi yanında her yıl üniversiteye katılan öğrenci sayısının makul bir adete indirilmesinin en doğru hareket olacağının düşünülmesidir.

Sonuçta görülüyorki yapılmış ve yapılacak olan tasarımlarda özeleştirinin gerekli ve faydalı olacağı kanısı ortaya gelmektedir ve gelmelidir.

Evet, bu yazıda adları geçmekte olan Sayın profesörler Sedad Hakkı Eldem, Arif Hikmet Holtay, Mehmet Ali Handan hocalarımız artık aramızda bulunmuyorlar, Kendilerinin Güzel Sanatlar Akademisi'ne ve Mimar Sinan Üniversitesi'ne vermiş oldukları hizmetin değeri çok büyüktür.

Değerli ustaları saygıyla anarım 1
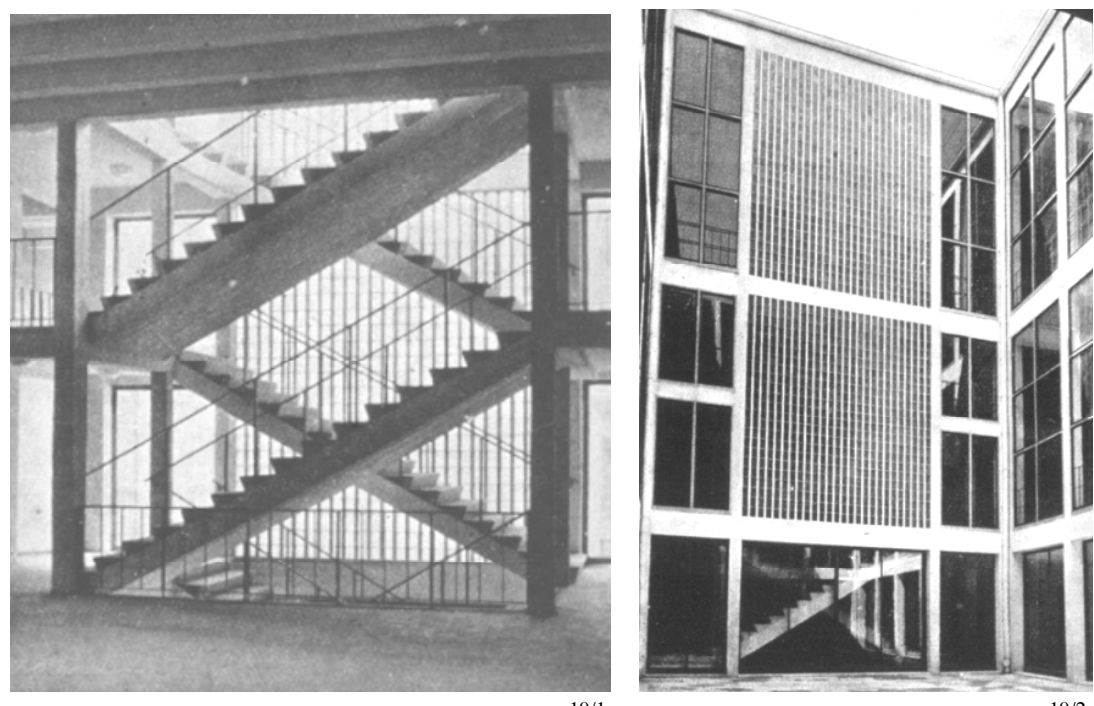

\section{KAYNAKÇA:}

Arkitekt (1954) Cilt 22, no 1-2, Nisan Eldem, S.H. (1973) "Meslekte 50 Yil”, M.S.Ü. / İ.D.G.S.A.' nın 90. Kuruluș Yılı Broșürüi

\section{$10 / 2$}

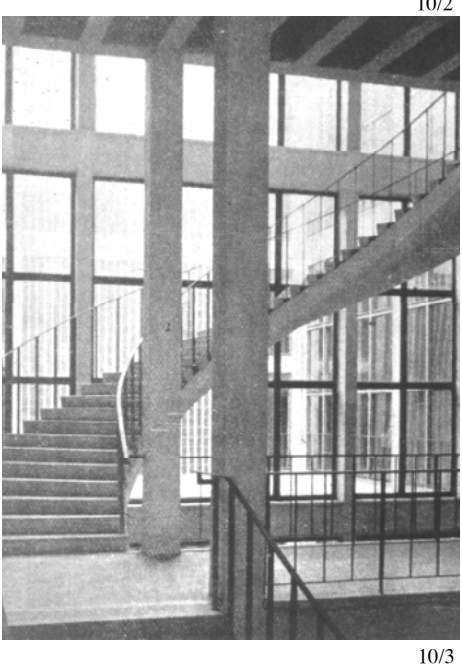

KAYBOLAN PERSPEKTIFLER

Resim: 10/I

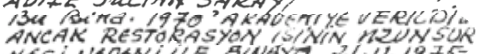

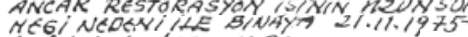
toritinde tosivilo?

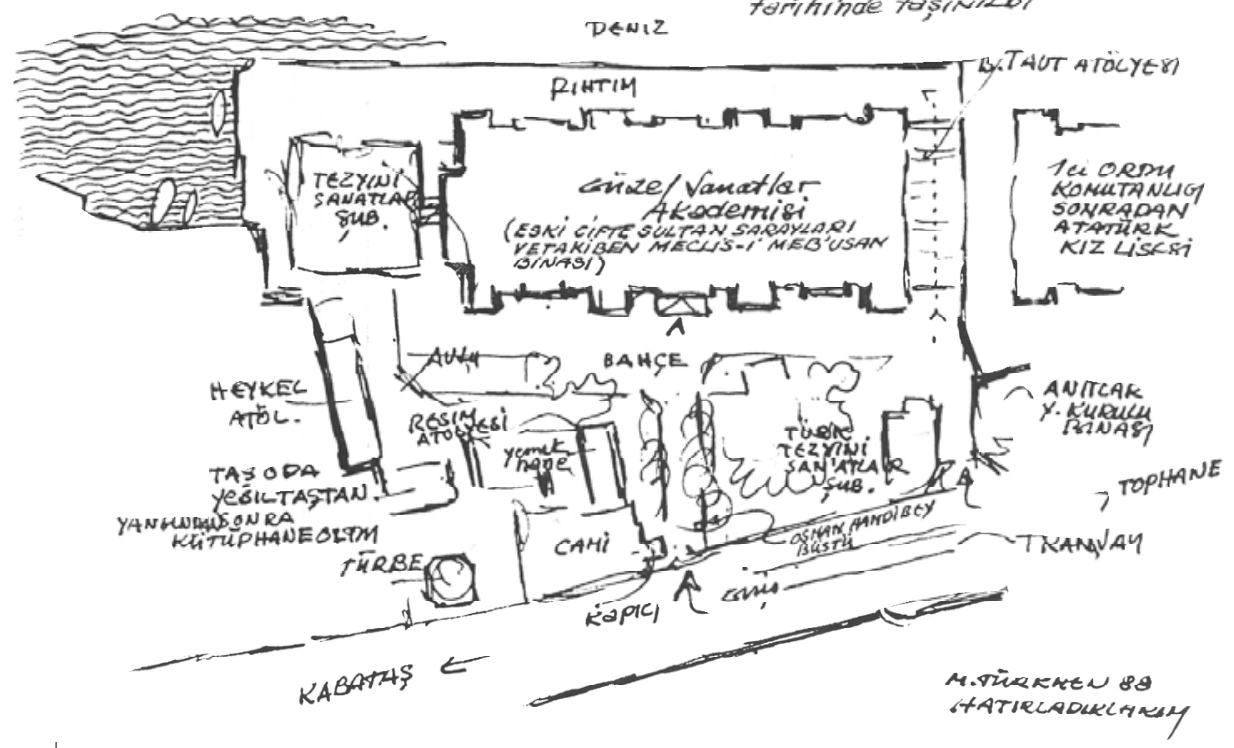

Yandaki merdivenin ve holün ışık ve hava aldı̆̆ı aydınlık.

Resim: 10/2

Osman Hamdi Bey Holünün bulunduğu binada (I.kısım inşaat) yeralan ana merdivenin bu görünüşü tüm güzelliğini, arasındaki avlunun katılımı ile almaktaydı. Zaten fotograf bu tadı tam anlamiyla ortaya koymaktadir.

Resim: 10/3

Mimar Sinan Holü'nün bulunduğu binanın ikinci katındaki merdiven mekânı ışık ve hava aldı ̆̆ aydınlığık (avlunun) değişik bir fonksiyona dönüştürülmesi sonucu yukarıdaki perspektifi kaybetmişti.

Resim: II

Güzel Sanatlar Akademisi'nin bahçesinin kamulaştırılmasından evvel vaziyet planı (1957 yilindan evvel)

8 Sayı I, Mayıs 1999 